\title{
Political Imbroglios in Kamila Shamsie's Home Fire and Mohammad Hanif's A Case of Exploding Mangoes
}

\author{
Muhammad Arfan Lodhi ${ }^{1}$, Sania Muqqadas ${ }^{2} \&$ Sobia Sikander $^{3}$ \\ ${ }^{1}$ Higher Education Department Collegiate Wing, Punjab, Pakistan \\ ${ }^{2}$ The Islamia University Bahawalpur, Rahim Yar Khan Campus, Pakistan \\ ${ }^{3}$ The University of Lahore Pakpattan Campus, Pakistan \\ Correspondence: Dr. Muhammad Arfan Lodhi, Higher Education Department Collegiate Wing, Punjab, Pakistan. \\ E-mail: samaritan_as@hotmail.com
}

Received: December 6, 2018 Accepted: December 30, 2018 Online Published: January 28, 2019

doi:10.5539/ells.v9n1p120 URL: https://doi.org/10.5539/ells.v9n1p120

\begin{abstract}
This research work aims at to scrutinize two novels of Pakistani writers, Mohammad Hanif's $A$ Case of Exploding Mangoes (2008) and Kamila Shamsie's Home Fire (2017) comparatively. Hanif's novel is about the ruling era of General Zia-ul-Haq and Shamsie's novel is about the difficulties of Muslim migrants in a foreign country. The purpose of this study is to accentuate the working of politics and political imbroglios at personal, social, civil/political, and military level; intermingling of religious values into political values; and conversion of politics into capitalism through Marxism theory which is originated by Karl Marx and Friedrich Engels in the mid-to-late nineteenth century, taken from Lois Tyson's book Critical theory today (2006). The researchers have substantiated through the comparative analysis of both novels that the use of politics in a positive way becomes the cause of peace and prosperity and the use of it negatively becomes the cause of creating disintegration and demolition in the society. This study spotlighted that whatever people do in their life, they do so to get personal benefits, political advantages and economic power. Conspicuous findings of the study reveal that both novels explicate intricate ideologies at personal, political, cultural and somewhat emotional levels. The novels display themes and stories, with slight manipulation of political and cultural facts and realities.
\end{abstract}

Keywords: Marxism, political imbroglio, Pakistani fiction

\section{Introduction}

\subsection{Background of the Study}

Kamila Shamie is a Pakistani English novelist who was born in Karachi on 13th August, 1973 in Pakistan. She got higher education in UK and now lives there. Shamsie's eight novels have been published since 1998 to 2017 which got worldly praise and fame. She has tackled the complexities of politics at personal and social level in the novel Home Fire (2017). She has accentuated these issues and complexities through the characters of Isma, Aneeka, Karamat, and Parvaiz who are Muslims and migrate from Middle East to London, and Eamonn who is a non-religious and son of a powerful political figure who is recently elected home secretary of London. Shamsie very tactfully described that how people use other people for their personal benefits. She clearly manifested that people exploit ethics, morality and relations in the name of love.

Mohammad Hanif, a journalist and Pakistani-British writer was born in Okara, Pakistan in 1964. He got his early education from Pakistan and then moved to London, and in 2008 he came back to Pakistan. He is one of the worldly acknowledged Pakistani writers. His three novels have been published, and he has written two plays and script of one film as well. His novel A Case of Exploding Mangoes (2008) is based on the life of military and conjectures on the crash of General Zia-ul-Haq's plane. Hanif skillfully has narrated the politics at personal, social, political/civil, and military level through the characters of Ali Shigri who is an air-force pilot and is pursuing the revenge for the murder of his father for which he thinks that only the chief of army staff is responsible. It also discusses the involvement of CIA spooks, generals, blind prisoners, and a tender-hearted and beautiful love story between two cadets. Tanveer and Arif (2014) voiced that Hanif's novel has great value because it describes in an apt manner the reality of Pakistani politics, the role of army, and army's interference in civil and public politics (p. 95). 
Both novels depicted politics but at different levels such as at personal, social, military, and civil/political level. Tyson (2006) has recounted Karl Marx's view that behind all human productions and events, there are peculiar historical/material reasons (p. 54). So, according to Marxists the build out of the superstructure of social, political or ideological realities is based on economics (ibid). The current study has highlighted the complexities and imbroglios of politics at different levels not only in Pakistani society but also in migrated Muslim families in foreign countries. The study has spotlighted the state where military has the right to take-over the country whenever it wants to do so. This study has also focused on the politics in personal relations and emphasized that how people gain personal benefits, do politics with other persons in the name of love and family, and in this way they play with their relations and exploit them. This study has pointed out the alliance among military officers, government of Pakistan, and USA which works as capitalism and shape the rules and laws of our political, military, social, and civil systems. These systems prevail in our society and dominate our lives.

\subsection{Rationale of the Study}

The working of politics at personal, social, military, and civil/political level is the cause due to which people at individual level and society as a whole suffers from devastation and desolation. The alliance between government and military officers creates capitalism, and dominate over the state where they work as capitalists to get personal benefits, and economic and political power. Politics in the name of love either within family or with other people destroy trust and relations; consecutively people become confused and distrusted to others. Political imbroglios are the cause due to which people become the victim of disillusionment because when they come to know that someone or something is not as good as they believe, their trust and hopes become perished, and they become totally disillusioned. These are the problems in Shamsie's Home Fire and Hanif's A Case of Exploding Mangoes on which no one has worked yet. So, the researchers attempted to go through intensive and comprehensive analysis of both novels to fill this gap.

\subsection{Research Questions}

1) What is the depiction of the politics in Shamsie's Home Fire and Hanif's A Case of Exploding Mangoes?

2) What kinds of political imbroglios at different levels are present in Shamsie's and Hanif's novels?

3) What are the reasons of the conversion of politics into capitalism in both novels?

4) How political mantles are represented/misrepresented Pakistani people, culture and society?

5) What are the causes of the intermingling of religious values into political values?

\subsection{Politics and Fiction}

The word politics is derived from the Greek word which means 'cities' affairs. It is a process through which decisions are being made for applying them to all the members of every group. Politics also refers to exercise and achieve the positions of governance; it means to get control over a state or human community. So, it is a practice or study of the distribution of resources and power. It is usually said that politics is all about the power. So, a political system is a framework which provides the political methods in any given society. Generally, politics includes anything which affects one's daily life such as the way through which a household or an office is managed, or how one group or one person exercises influence over another. Hence, the idea that "politics is everywhere", informal politics is understood typically as everyday politics. It is stated in Merriam-Webster dictionary that politics means the relations' total complex between all the people who live in society; conduct or relation in an experience's specific area as seen or dealt with especially from a political point of view such as ethnic politics, office politics etc. Adams and Dyson (2003) said that according to Aristotle, man is a political animal by nature. Dorling (2016) said that a better politics is that which can make the future generations to be happier with goals of better health and greater well-being rather than maximization of wealth. Dorling further said that not just our friends and family members but our all fellow citizens who live around us and whose lives are interlaced with our lives and will affect us at some point for good or bad.

\subsubsection{Marxism}

According to Tyson (2006), although in Europe the Communist Bloc has failed but still those communist societies which claim they are based on the principles of Marxism developed by Karl Marx, are in reality the oligarchies in which the guns and the money are controlled by a small group of leaders and through the physical intimidation its policies are forced on a population by keeping in line. Karl Marx's theory 'Marxism', can still give us a meaningful way to understand the current events and the history even if the Communist countries were the true Marxists societies and even if all those societies had failed (ibid). He said that according to Marxists, there is a force to get economic power, material and personal benefits at the back of all activities of life such as 
political, social, and cultural. In the terminology of Marxist, material circumstances become referred through economic conditions, and the ideological or social or political atmosphere which is generated by the material conditions, is known as the historical situation. So, for Marxist critic, without understanding the specific historical/material circumstances, neither human productions nor human events can be understood, in which those productions and events occur, because all human productions and events have specific historical/material causes. According to the Marxists, the socioeconomic class's differences divide the people in the ways that are more significant than the differences in ethnicity, religion, gender, or race. So, the lines are drawn for the real battle between "haves" and "have-nots", between the proletariat and bourgeoisie.

'Religion' is an ideology to which Karl Marx called "the opiate of the masses" that helps the faithful poor people become satisfied with what they have in life. So, according to Karl Marx religion works as a tranquilizer might do. For Marxist analysis, the question of the existence of God isn't the fundamental issue, rather an organized religion, what the human beings do in the name of God, is the focus. Tyson (2006) has explained that according to Marxism, the capitalism is a way in which the imperialist governments colonize the consciousness. To colonize the subordinate peoples' consciousness means to convince them to see their situations in the way imperialist nation wants from them to see it. So, Marxism focuses on historical/material forces that are the politics and the ideologies of the socio-economic systems which shape the groups' and individuals' behavior and psychological experience.

\subsubsection{Capitalism}

According to Scott (2006), capitalism is the governance system for the economic affairs that has emerged in the different settings and which continues to move towards progress over the time. Capitalism is a system which is economic and political at the same time, or we can say that for short it's a system of the political economy. As a result, capitalism evades a simple definition. It is defined in The Macmillan Dictionary of Modern Economics that it is an economic, social, and political system in which private persons controlled and owned the most part of property including the capital assets. It contrasts with an old economic system which is called feudalism, in that it is characterized by the labour purchase for the money wages as opposed to direct labour which is obtained through the command, custom or duty in feudalism. The price mechanism under capitalism is used as a signaling system which distributes the resources between uses.

\subsection{Political Imbroglio}

Political imbroglio means a state of great confusion which creates complex situation that is violently intricate and becomes the cause of painful and bitter misunderstanding as created by Shamsie and Hanif in their novels Home Fire and A Case of Exploding Mangoes respectively at personal, social, civil, political, and military level.

Since the last few decades, due to what is happening in the political scene, Pakistan is facing the challenges of insecurities, social unrest, and political instabilities. Ashraf (2014) uttered that in the global region, due to its strategic and geopolitical standing, South Asia is the most targeted region, and the stereotypical convictions such as fundamentalisms and nationalism have categorized the people of South Asian region in the stifled cabins of creed, nation, cast, culture, and religion. So, in such type of critical time, literature can no longer remain just a piece of story which is used to entertain, rather it's bound morally to fill the gaps for the sake of breaking those boundaries that leads us to destruction.

Paul (2016) said that the book The Army and Democracy enhances our understanding to a highly complex country 'Pakistan' and a comprehensive and rich analysis of how the development of the military of Pakistan and its continuously holding control over politics makes for the country impossible to create proper democracy and appear itself a proper democratic state. There are many writers all over the world who have focussed their writings on the emerging themes of politics, power, and political imbroglios at different levels. Jan-Werner Muller, a British writer, has written in his book What is Populism? published in 2016, recent decay of democracy in the Europe. Rodrik (nd) voiced in the Harvard University Press that Jan-Werner Muller confronts in this book to the key questions which are raised by the populism's globally resurgence. How is populism different from politics' other kinds, why is populism too much dangerous and how can populism be controlled? According to Rodrik, populism's depiction by Muller as the moralistic and anti-pluralist of democracy is masterful. Fatunla (2015) has appreciated Dambudzo Marechera and his second novel Black Sunlight. Marechera was a poet and novelist from Zimbabwe. According to Fatunla, in form, the second novel of Dambudzo Marechera, is deeply experimental; mocking the African nationalism's certitudes and other ideologies which are used to justify the authoritarian rule across Africa. 


\subsection{Shamsie as a Novelist}

Kamila Shamsie is a Pakistani-British novelist. She used to write in the English language. She is the daughter of the famous literary compiler, editor and journalist Muneeza Shamsie. She is Attia Hosain's niece and the granddaughter of Begum Jahanara Habibullah who was also a writer. Kamila Shamsie attended Karachi Grammar School because she was brought up in Karachi. From Hamilton College, she did BA in creative writing and at the University of Massachusetts Amherst, she did MFA from the MFA Program for writers and poets, and Shamsie was influenced by Kashmiri poet Agha Shahid Ali there.

Kamila Shamsie has written eight novels since 1998 to 2017. She wrote In the City by the Sea in 1998, Salt and Saffron in 2000, Kartography in 2002, Broken Verses in 2005, Burnt Shadows in 2009, Offence: The Muslim Case in 2009, A God in Every Stone in 2014, and Home Fire in 2017. In a review in Real Simple on Shamsie's Home Fire, it is stated that she addresses about the conflict between what according to law is right versus what we as a human being feel to be right, and what for our family, we will sacrifice. According to O, the Oprah Magazine, Shamsie's Home Fire depicted the present world, and scrutinizes the family's pull and radicalism's roots. She said that this novel revealed skillfully all the ways where personal is as political as political is personal Schaub (2017) lauded Shamsie for using simple, beautiful and smooth language in Home Fire. Shamsie's books have been translated in different languages. She is primarily a reviewer and columnist for The Guardian. She became the judge for the several literary awards including the Guardian First Book Award and Orange Award for New Writers. She was added in 2013 in Granta list of 20 best young writers.

\subsection{Hanif as a Novelist}

Mohammad Hanif is a journalist and Pakistani-British writer. He is one of the worldly acknowledged Pakistani writers. Hanif was born in 1964, Okara, Pakistan. He did graduate from Pakistan Air Force Academy as a Pilot Officer but left it to follow journalism as a career. He worked for The Washington Post, News line, and India Today. He has written plays for screen and stage also, including critically acclaimed BBC drama and feature film The Long Night. His novel A Case of Exploding Mangoes was short-listed for The Guardian Book Award, long-listed for the Man Booker Prize, and won Commonwealth Writers' Prize for Best First Novel. Hanif was the BBC Urdu Service's head in the London and now he works as their special correspondent which is based in Karachi.

Inskeep (2012) said that $A$ Case of Exploding Mangoes is based on real story of Zia-ul-Haq, a Pakistani dictator who in 1988 died due to the plane crash. Till now, Mohammad Hanif has written three books: $A$ Case of Exploding Mangoes (2008), Our Lady of Alice Bhatti (2011), and The Baloch who is not missing and others who are (2013). Hassan (2016) vocalized that in this novel Hanif's use of language shows sarcasm at great extent, and he does great effort to re-write on one of the Pakistan's national history's darkest time period (p. 95, 101). Tanveer and Arif (2014) said that Hanif's this novel clearly manifests the personality of General Zia-ul-Haq both as Chief of Army Staff and as the president and he remained a perfect example of patriot during his rule's era over Pakistan, but he exploited and inflated political polarization in Pakistan also. Filkins (2016) voiced that when Hanif was working for BBC, he had gone to office with hope that Pakistan wouldn't make any news but it seldom happened. For a writer who is engaged with the politics, there's been a benefit. Often extraordinary literature is being produced by the politically turbulent societies: postwar Latin America, India after the independence, Russia in twilight of tsars, and Pakistan chaotic since 1947, has served Mohammad Hanif as ideas' and characters' wellspring.

\section{Methods}

\subsection{Research Framework}

The study was exploratory in nature and scope. To analyze political imbroglios in Kamila Shamie's novel Home Fire and Mohammad Hanif's novel A Case of Exploding Mangoes, Tyson (2006) Critical theory today, based upon different theories from which Karl Marx' and Friedrich Engels' theory Marxism was adopted, which was published in the mid-to-late nineteenth century. The researchers have explored political complexities at different levels and intermingling of religious values into political values under this theory. The data was collected, analyzed, and interpreted qualitatively. By using this theory, Shamsie's novel Home fire and Hanif's novel $A$ Case of Exploding Mangoes were compared and the political imbroglios were explored at different levels in both novels, conversion of politics into capitalism, intermingling of religion with politics, and also the similarities and dissimilarities in both novels have been investigated.

\subsection{Population Framework}

Eight novels of Kamila Shamsie and three novels of Mohammad Hanif were the population of the study. 
Table 1. Accessible population framework

\begin{tabular}{lllll}
\hline No. & Books & Authors & Year of publication & Publisher \\
\hline 1 & In the city by the sea & Kamila Shamsie & 1998 & Bloomsbury \\
2 & Salt and Saffron & Kamila Shamsie & 2000 & Bloomsbury \\
3 & Kartography & Kamila Shamsie & 2002 & Bloomsbury \\
4 & Broken Verses & Kamila Shamsie & 2005 & USA \\
5 & Burnt Shadows & Kamila Shamsie & 2009 & Bond Street Books \\
6 & Offence: The Muslim Case & Kamila Shamsie & 2009 & Seagull Books \\
7 & A God in Every Stone & Kamila Shamsie & 2014 & Bloomsbury UK \\
8 & Home Fire & Kamila Shamsie & 2017 & River Head \\
9 & A Case of Exploding Mangoes & Mohammad Hanif & 2008 & Knopf \\
10 & Our Lady of Alice Bhatti & Mohammad Hanif & 2011 & Jonathan Cape \\
11 & The Baloch who is not missing and & Mohammad Hanif & 2013 & Human Rights Commission of \\
& others who are & & Pakistan \\
\hline
\end{tabular}

\subsection{Sampling Statistic}

For the present study, the whole texts of both novels, Kamila Shamsie's Home Fire and Mohammad Hanif's $A$ Case of Exploding Mangoes were taken as the sample from the whole population parameter.

Table 2. Sample of the study

\begin{tabular}{llll}
\hline Books & Authors & Publication & Publisher \\
\hline Home Fire & Kamila Shamsie & 2017 & Riverhead \\
A Case of Exploding Mangoes & Mohammad Hanif & 2008 & Knopf \\
\hline
\end{tabular}

\subsubsection{Sampling Technique}

The researchers applied mixed purposive sampling technique on the whole texts of the two novels Home Fire by Kamila Shamsie and $A$ Case of Exploding Mangoes by Mohammad Hanif. Mixed Purposive sample is a non-probability sample that is selected based on a population's characteristics and the study's objectives. This type of sampling is also known as subjective, selective, or judgmental sampling. In such type, typical case sampling and critical case sampling strategies were mixed on specific purpose and explicit nature of data.

\subsection{Data Collection Tools}

Data collection is a process to gather and measure the information on the variables of interest in an established systematic way that enables to answer the stated research questions, test the hypothesis, and evaluate the results. The sources of the data collection were both primary and secondary. The primary source was the texts of both novels and secondary source consisted of books, journals and other archived or web resourced data. Both primary and secondary sources were used for three main tasks of the study:

\subsubsection{Observation}

Observation is an approach to systematic data collection in which a researcher uses all his senses to investigate the people in naturally occurring situations or natural setting. There are two types of observation: quantitative and qualitative. Qualitative observation deals with the data that can be observed through our senses. They don't involve numbers or measurements. For the present study the researchers observed and collected the data in a systematic way. The researchers used positivist ontology to observe the text of the novels in order to find patterns of similarity and contrasts.

\subsubsection{Critical Thinking}

Critical thinking is defined as a combination of reflection, problem solving, and logical reasoning. The researchers have critically analysed the primary and secondary data through logical reasoning. The claims were supported or rejected on the basis of logical but substantial arguments.

\subsubsection{Codification}

To codify means is to arrange the things in a systematic order to make something a part of a classification or system to categorize. The researchers have compiled and organized the data through codification. What was happening in the data, the researchers have synthesized and summarized it by codification. The basis for 
developing the analysis was the coding criteria that created a link between collection and interpretation of the data.

\subsection{Data Analysis}

It's the process of analyzing the qualitative data that typically involves categorizing or coding the data. The data was analysed through applying the theory of Marxism and its sub-theory capitalism. By using this theory, Shamsie's novel Home Fire and Hanif's novel A Case of Exploding Mangoes were compared and the political imbroglios were explored at different levels in both novels, intermingling of religion with politics, conversion of politics into capitalism, and also the similarities and dissimilarities in both novels have been investigated.

\subsubsection{Framework of Analysis}

Framework is a basic structure underlying a concept, text, or system. After going through the textual data, following framework was devised to undergo content analysis of this study.

Table 3. Framework of analysis

\begin{tabular}{lll}
\hline Categories & Sub-categories & Further Types \\
\hline Politics & Political Imbroglios & Levels of Political Imbroglios \\
Political Levels & Personal Level & \\
& Social Level & \\
& Civil/Political Level & \\
& Military Level & \\
Marxism Element & Capitalism Elements & Politics from Marxism Perspective \\
& & Conversion of Politics into Capitalism \\
& & Intermingling of religious values into political \\
& & values through Marxism perspective \\
\hline
\end{tabular}

\section{Data Analysis}

Both novels have been written in the most artful and beautiful manner. Due to the politics at large scale, both novels are filled with political imbroglios. All the main characters of both novels face complex and intricate situations which become the cause of destruction. Hanif (2008) describes the negative effects of politics and political imbroglios and further mentions that people become blind and can't see anything clear and positive. As Secretary General in the novel tells Ali Shigri in the dark prison that he feels that he has gone blind because he couldn't see anything. He rubbed his eyes but still didn't see anything, then he says, "I knew I am not blind. I swear I can't see anything. They brought food, they opened the door but I didn't see anything. Not a thing" (ibid, p. 190, 191). These lines clearly manifest that due to the working of politics, people become confused and perplexed that they can't understand the politics behind anything, and even can't differentiate between right and wrong as Secretary General can't differentiate between night and day. They give bribe and luxurious life for doing wrong according to their demands but we can't imagine that how much they exploit and use us. From this Hanif (2008) pointed out that army, politicians, government, and capitalists all make the lower-and-middle class blind so that they can't see their tricks and mischievousness. They provide them food; they give them freedom to move in the society and live life but they can't bear and give permission if any one tries to speak or stand against them. They are just being used for these capitalists' purposes. Hanif (2008) further points out politics through which Pakistan army and government use and suppress the lower and middle class of Pakistan, and also America uses Pakistan army and government, when Ali Shigri says, "You want freedom and they give you chicken korma (p. 168)". It shows that Pakistan army and government use the people for their own personal benefits and in return provide them to some extent luxurious life. Same is the case with the America, he uses Pakistan government for its own purposes and gives them luxurious life and everything which they demand. Pakistani people, who are suffering due to these government officials, want freedom. They don't want to do what they demand but they do it to live and survive in the society. They get punished if they refuse for being used. As, it happened with Colonel Quli Shigri and Secretary General in the novel. According to Hanif (2008), General Zia-ul-Haq during his ruling era did politics by using religion. He intermingles religion with politics so that people trust him and consider him pious who is religious and can't do anything wrong. He did this so that people can't see the politics and treachery behind his religious cloak. He hanged Zulfiqar Ali Bhutto to get political and economic power. He wanted to be the most powerful man of the country. Due to his greediness General Zia hanged Zulfikar Ali Bhutto. He knew that until Bhutto's death, he can't be the most powerful man of the country because people liked Bhutto. The leaders of the world requested Zia not to hang Bhutto but he didn't listen and 
consider to anyone's plea and due to his uncontrollable greediness for getting power, he signed Bhutto's death warrant. Zia's conscience pricked him because of his wrong deeds and he always asked his Chief of Security, Brigadier TM who wants to kill him (ibid). Despite of “... three Special Services Group platoons surrounding his residence, a battery of anti-aircraft guns, and six different-coloured phones representing six different hotlines arranged on a table in his bedroom... (Hanif, 2008, p. 35, 36)", he still always felt himself unsafe even in his presidential home. He made friendly relations with America and supports him in Afghan war against Soviets through Pakistani army. America has too much interference in our country that's why Hanif taunts when Bannon says, "The USA has got satellites with cameras so powerful they can count the exact number of hairs on your bum (p. 29)". America uses his power to make other countries his subordinate and interferes in their social, civil, and military affairs. General Zia himself got dollars and enjoyed his power, and the fame in the world as the bravest man who stopped the different wars, but our army soldiers got nothing who were the real fighters and gave their lives to win the wars for America. The novel destroys facts of the event too. According to falsely alleged viewpoint of Hanif (2008), Zia didn't want to leave his position and power to anyone else at any cost, so, he ruled for 11 years until his subordinate army officers who also wanted that position and power, couldn't wait any more and did politics to kill him and they succeeded but they themselves also die with him except the one, General Beg. So, what politics Zia played with others to take that political and economic power, others played with him. General Akhtar wanted political and economic power and all his life he had cheated his superiors to take personal benefits and also their position and power (ibid). He played politics not only to cheat his superiors but also to create political imbroglios and battles between different countries. That's why he says that he was:

The man who has spent a decade creating epic lies and having a nation of one hundred and thirty million people believe them, the man who has waged epic psychological battles against countries much bigger, the man who credits himself for bringing the Kremlin down on its knees, is suck for an idea (p. 355).

The above lines are satire on General Akhtar that he was the man who considered himself a master mind and very tricky, and had done great politics to create battles and imbroglios between different countries, was going to be sucked due to his own idea, it means he was going to be killed in plane crash.

Zia exploited Pakistani nation by misusing the religion. He introduced and passed many good Islamic laws in the country but didn't implement them strictly, neither followed himself also. He showed himself too much religious that in his absence other army generals called him mullah, "A mullah without a beard, a mullah in a four-star general's uniform... (p. 42)". During Zia's first meeting with his subordinates after taking hold over the country, all were confused that "... a meeting was a meeting and mixing religion with the business of running the country was a concept not comprehensible to them (p. 39)". His subordinate army officers do politics to take his position and political and economic power. As we see General Akhtar, General Beg, and Major Kiyani who do politics to get personal benefits, and maintain political and economic power. Everybody wants more than what he has. Ali Shigri, a cadet, does politics to take revenge of his father's murder. Ali Shigri, General Akhtar, General Beg, Major Kiyani and CIA spooks create political entanglement to get their personal benefits and which take the life of General Zia-ul-Haq, General Akhtar, Major Kiyani, Obaid ullah, Arnold Raphel, and some other soldiers who are boarded at Pak One. All the characters become confused and mistrusted due to the working of politics that everyone considers the other his enemy who can cheat him any time for his benefits.

There is also politics at physical level in Hanif's novel. General Zia was doing politics with her wife. He cheated her wife and hid his relation with Joanne. And the First Lady started to suspect her husband when she came to know that they would stay first at Lufkin and asked her wife to pack his safari suit for the meeting at Lufkin because Zia was not used to this type of dress in official meetings. The First Lady thought "the old man was definitely up to something fishy (p. 118)".

Mohammad Hanif put emphasis on politics at social level in this novel. Media plays vital role in creating political confusions and complexities in any society. Newspapers and news channels presented and highlighted what the army and government asked them to do. They get important posts although they are not capable for these posts. But they get these posts because they make the government happy by working according to their orders. Hanif (2008) describes corruption and politics of editors when he says,

General Zia had tried to cultivate these editors himself and found out that they were the kind of intellectuals who prayed with him devoutly then rushed off to get drunk in the hotel rooms that his government provided them, with the booze that the Information Minister bought them. And the following morning their editorials were messy transcriptions of what General Zia had told them between their prayers and the boozing sessions (p. 113).

In the prison of Lahore Fort, the Secretary General of All Sweepers Union told Ali Shigri that he was being caught in charge of plotting to kill General Zia. To inaugurate National Cleanliness Week, his central committee 
sent an invitation to Zia to which he opposed. He didn't want to invite him because "his coup d'état was a historic setback for the workers' struggle against the nationalist bourgeoisie (p. 165, 166)". This shows that army's revolution which was brought under the aegis of General Zia, was non-statutory political change. Army itself doesn't want that common people grow economically and politically. They don't want that anyone else except them get economic and political power and get hold over all natural and human resources of the country (ibid). Hanif points out the hold, involvement, and politics of army in agriculture and at social level also, when the Secretary General says that he proved through the analysis of the experience of their peasants' movement that "our modes of production are determined by the petty bourgeoisie not what they call feudal landlords, ... ( $\mathrm{p}$. 178)". Hanif has used the word 'bourgeoisie' in the novel again and again for the army. So, in the above quoted sentence, it represents army. Although landlords should decide what modes of production should be used for cultivation but instead of landlords, army decides it. It means that army has the hold on even agriculture also. In this novel, we can see politics at political/civil level also. According to Zia, Zulfikar Ali Bhutto was the real threat for the country, although he was not. Zia created confusions just to get economic and political power. All the people who are in power always create confusions to threaten the nation and misguide them so that people can't understand their politics. He had left all the activities outside the Army House. When his Information Minister wanted to record his address to the nation in the Army House, Zia didn't like the speech which his Information Minister had written. For Zia people will think that he is a prisoner in his own Army House and also that he is a fool and suffering from some type of mental illness. For him the speech has no emotions and it's dead. It means there must be a speech through which he could play with emotions and feelings of the nation. According to him, to tell the nation that they are facing threats is poetic. He says, "Name those threats; make them more-make them more threatening (p. 67)". Zia forced on making the threats more in quantity and also more threatening. It means that Army and government always create confusions deliberately to make the nation fool and show their importance. They themselves create confusions and threats to get their own personal benefits, and economic and political power, and then sometimes themselves solve them to show their value and power. Zia pointed out to one paragraph in his speech that says, "I will not move into the President House because it has blood in its foundations doesn't make sense. Whose blood? (Hanif, 2008, p. 67)". He asked his Information Minister, "to say something about blood-sucking politicians. Say something about poor people. You do know there are poor people in this country? (p. 67)". Then Zia threatened his Information Minister through his power when he says, "I am sure you don't want to become one of them (p. 67)". It means if he wouldn't write the speech according to which Zia wanted then Zia will take his rank and also the luxurious life from him and make him poor. This is what how army and government use people for their own purposes and if they can't do so and if dare to refuse to do then in result of it they have to suffer from critical and too much crucial conditions.

Same situations can be found out in Kamila Shamsie's Home Fire. In this novel Shamsie (2017) deals the working of politics at personal, social, and civil/political level to aggravate the effects of political embarrassment on our relations, on our lives, on our society, and on the world, which become created just due to the wrong use of politics. In this novel, Shamsie highlights intermingling of religion with politics through the character of newly elevated Home Secretary of Britain, Karamat Lone who has Muslim background. He first uses religion to get the support of Muslim community to get the political seat of MP. The Muslim community fully supports him so that he will help them in solving their problems in Britain but when he gets the MP seat, he does nothing for them instead create more problems for them. So, the Muslims turn their back to him. But then he gets the seat of Home Secretary through doing treachery and politics. In the novel, Karamat Lone, Aneeka Pasha, Isma Pasha, and Farooq do politics and create political imbroglios, which create intricate situations that nobody is ready to trust on the other. As Aneeka does not trust upon Isma, her elder sister; Isma on Parvaiz, her younger brother; Eamonn on Aneeka, her beloved; Eamonn on his father, Karamat Lone; Karamat Lone on his son, Eamonn; Terry on her husband, Karamat Lone; and Parvaiz on Farooq, his friend and her sisters, Aneeka and Isma. Due to their political attitude and actions, too much intricate and horrifying situation is created that ruins the two families and takes the life of Aneeka, Eamonn, and Parvaiz. As through Parvaiz, Shamsie points out the political imbroglios and its negative effects when he says, "Impossible here to know who was a true believer and who was playing along for any of a host of reasons from terror to avarice. The price of letting your mask slip was far too high for anyone to risk it (p. 169)". We can see personal politics in this novel. Isma tells police about his brother, Parvaiz's departure to Istanbul. Kamila Shamsie points out what happens if we hide things from our close relations. So, here Shamsie highlights the bad effects of politics in relations. Isma without taking Aneeka, her sister in confidence, gives information about her brother's activities to police. When Aneeka comes to know about it, she was being hurt and confused. Isma says to Aneeka that one day police would have found out all and Aneeka says, “'You don't know that.'... 'They might not have.' (p. 42)". Aneeka says that when Parvaiz feels that he has done a mistake, “... he could have come home. ... You have made him not able to come home.' (p. 
42)". Isma tells her that there was no way to do anything for her brother so, she did what she could do for her sister and herself. Isma deceives Aneeka, "We are in no position to let the state question our loyalties. Don't you understand that? If you co-operate, it makes a difference (p. 42)". Isma says that she doesn't want that her sister may suffer due to her brother that's why she informed police about him. But Aneeka says that she must suffer because Parvaiz has gone. Isma replies that Parvaiz has done this, not she. Isma voices, "When they treat us this way the only thing we can do for our own sanity is let them go (ibid)". But Aneeka disagrees with Isma and says, "Parvaiz is not our father. He's my twin. He's me. But you, you're not our sister any more (p. 42)". Aneeka loves her brother. She can do anything for him. Through these lines, it becomes clear that how politics exploits personal relations. Isma's politics to save her sister and herself from difficulties creates intricate situation. Aneeka, her younger sister started to hate her. That's why Aneeka says, “... You betrayed us. Both of us. And then you tried to hide it from me. Don't call, don't text, don't send me pictures ... We have no sister (p. 42)". Now we can see clearly that how politics creates confusions in a family that becomes the cause of complex situation and the family members become mistrusted. No one in the family trusts on the other anymore. Eamonn goes at Aunty Naseem's home to give them Isma's parcel. Aneeka doesn't like Eamonn's presence at her Aunt's home but then a plan comes in her mind and she thinks to take advantage from it and asks Eamonn to take her to his home if he lives alone. At Eamonn's home, Aneeka starts to work on her plan to attract Eamonn towards her. Both have close intimacy. Both show intimate love for each other. After spending the first night together, Eamonn feels her everywhere in his home. In the morning, Aneeka awakes early for the morning prayer and Eamonn sees her praying in full dress. He asks her after completing her prayer, "What were you praying for? (p. 70)" while Aneeka starts unbuttoning her shirt. Aneeka says, "Prayer isn't about transaction, Mr Capitalist. It's about starting the day right (p. 70)". It means that what human beings do it's not compulsory that it will be for money because all are not capitalists and not work to get money all the time. They have other preferences in their life than money as for Aneeka in the novel. Shamsie (2017) puts satire on capitalism that every time they work and think to increase their economic power. Aneeka tries to trap Eamonn through politics. She says to Eamonn that she didn't mind what his father had done to her father but he is unforgiving for all this and she doesn't like if Eamonn is like him while she kisses frantically at his mouth, neck, and jaw to make him involve in her passionately. Aneeka succeeds in making Eamonn to stand against his father for her so, she asks, "What if you were the one asking him to do the forgiving? (p. 80)". Eamonn asks her that if she wants from him that he should ask his father about her father or any other family member but she refuses. She says that she wants to know about Eamonn that what his father can do for Eamonn. Eamonn says, "He's one kind of person as a politician. Another kind as a father. There's nothing he wouldn't do for me (p. 80)". These words show that due to power Karamat Lone can do anything either right or wrong. This is what Aneeka wants to know so she says, "That's good... That's how it should be (p. 80)", and during all this discussion she continuously loves him. Eamonn asks Aneeka about her brother, Parvaiz' activities in Syria and Raqqa if they are fighting there? Aneeka tells, "God, no! He's with their media unit (p. 95)". Then Eamonn understands what her brother does there so, he speaks, "Their. The black-and-white flag, the British-accented men who stood beneath it and sliced men's heads off their shoulders. And the media unit, filming it all (p. 95)". With the feeling of rage and fear he starts to destroy the plants while Aneeka tries to stop him and pulls him inside the room. Aneeka says to Eamonn, "Fight like a man, not a boy (p. 96)", and Eamonn asks her in reply, "That kind of advice that gets passed down from father to son in your family? (p. 96)". At that moment Eamonn feels Aneeka misfit in his home. Aneeka surprises on what Eamonn says but she turns to her plan and tells Eamonn that her brother wants to come back home. Eamonn voices that now her brother should live there what he has chosen for him. Aneeka requests Eamonn for help and he asks, "Why did you get into the Tube with the Home Secretary's son that day? (p. 96)", and she replies that she did that because she thought that he is beautiful. Eamonn speaks with full anger, "Don't lie to me (p. 96)", then, Aneeka speaks the truth with very low voice, "... I thought the Home Secretary's son could help my brother come home and avoid charges (p. 96)". Shamsie through these words accentuates politics in close relations and also Marxism that people use their relations to get their personal benefits as Aneeka is doing. The above quoted line makes it clear that Aneeka is using him and cheating him for bringing her brother back. Shamsie points out here that due to politics, complex situations become created and people become mistrusted and confused as Eamonn is, so, he says that he felt the pain like which he never felt before and asks, "That's what this has all been about? (p. 97)". She says no and tries to take his hand but he physically pushes her away from him. Eamonn doesn't believe her and says that she has done much with him with love drama, so, Aneeka says, "You were hope... How can anyone fail to love hope? (p. 97)", Eamonn voices, "A love that's entirely contingent on what hope can do for your brother (p. 97)". These words show that Eamonn now comprehends the whole planning and politics behind Aneeka's love drama. Aneeka tells him that she is worried due to her brother because he wants to come back home but Eamonn's father won't allow him. She says, "I'm so tired of it. I want 
to be here, completely. With you (p. 100)". Kamila Shamsie herself comments upon what Aneeka says, "It was what she'd say if she were still only trying to manipulate him. It was what she'd say if she'd really fallen in love with him (p. 100)". But Eamonn loves her so, he takes her in his arms and asks to tell him all about her brother because he is ready to help her (ibid). Farooq meets Parvaiz in Britain and traps him. He exploits Parvaiz emotionally for being a son of martyr and convinces him to continue his father's good work at Raqqa. Farooq tells him that his father liked to be known from his son's name Abu Parvaiz to provoke his love for his father. Parvaiz decides to go with Farooq for knowing about his father and taking revenge of him when he sees the picture of a man in the desert with his head cut off in the same dress as his father used to wear, he can't bear the pain at the thought that may be his father was also treated like that. Parvaiz comes to know from Scotsman at Raqqa that when Farooq meets Parvaiz in Britain, he was giving training to his cousins there but Farooq speaks lie to him. Then Parvaiz comes to know about Farooq's cleverness, politics, hypocrisy, and business and wants to kill him. One day he runs out of their villa and tries to go back to Britain but Farooq kills him.

We find politics at civil/political level in Shamsie's novel too. Isma meets Eamonn and tells him why she doesn't like his father. She tells about his father and her whole family. She tells about what has happened with her father and that his father could do anything for them but he didn't do because he just wants to save his political seat and reputation as a British MP. It shows that people don't help each other so that they can be good in the book of powerful people who can be British or Americans etc. They do so because they don't want to lose the endowed facilities, luxuries, and power from them. Isma tells him all about the treatment of the British government with her family for being Muslim on just suspecting to be involved with terrorists. They didn't know even that her father was alive or dead. Kamila Shamsie accentuates politics of Karamat Lone to prove himself a British and make his political position stronger when Eamonn watches a video of his father addressing to the students at the predominantly Muslim school in Bradford in which he says,

There is nothing this country won't allow you to achieve-Olympic medals, captaincy of the cricket team, pop stardom, reality TV crowns. And if none of that works out, you can settle for being Home Secretary. You are, we are, British. Britain accepts this. So do most of you. But for those of you who are in some doubt about it, let me say this: don't set yourselves apart in the way you dress, the way you think, the outdated codes of behaviour you cling to, the ideologies to which you attach your loyalties. Because if you do, you will be treated differently - not because of racism, though that does still exit, but because you insist on your difference from everyone else in this multi-ethnic, multi-religious, multitudinous United Kingdom of ours. And look at all you miss out on because of it (ibid, p. 87, 88).

Through Karamat Lone's this speech, Shamsie satires on the politics of Muslims who leave their religion, their culture, and their ethics and values to get political and economic power and also the Non-Muslims who use Muslims to exploit other Muslims. As in the novel, British government is using Karamat Lone against Muslims. The above quoted lines clearly manifest that Muslims are being treated bad due to their Muslimness and if they leave their religion, change their ideologies, and change their dress style they will be known as British. In other words, if Muslims do everything according to British, then they become accepted as British otherwise not. Aneeka loves her brother and because her brother wants to come back home, that's why she takes stand against British government and demands to allow her brother's dead body back in Britain, "He was a beautiful, gentle boy. Don't you try to tell me who he was. I knew him from the day he was born. Shame on you, Mr Home Secretary. Shame on you! Give us our boy to bury, give his mother the company of her son in the grave (p. 191)". Kamila Shamsie accentuates here the courage and boldness of a girl who is even a girl but can do anything to save her relations. All newspapers and TV channels present all information about the terrorist, Parvaiz Paha. They tell that Parvaiz was working with ISIS' media wing which is responsible for the fighters' and so-called jihadi brides' recruitment, and that the Home Secretary is going to pass a new law that, "Under present rules only dual nationals or naturalized citizens with a claim to another nationality can have their citizenship revoked... citizenship is a privilege not a right or birthright (p. 198)". It means that people of Britain now can keep only one identity and that is British and their citizenship will be cancelled if they are being involved in any act against UK In appearance, this law looks positive because through this all British will be equal in every manner but Karamat says this for his own benefit because he himself has dual nationality, and through this he wants to save himself and proves himself British. But he forgets that British people are so prejudiced and they will never ever accept any Muslim having political and economic power in their country or somewhere else.

There's also politics at social level in Kamila Shamsie's novel. Eamonn thinks that whenever Muslim events came, Eamonn's father was busy to celebrate British's and Americans' events with them. Karamat intentionally avoids Muslims' events. He doesn't care that his family is with him or not. He just tries to show himself one of those British and Americans to get political power. When Eamonn goes at Aunty Naseem's home, he enjoyed 
Pakistani hospitality there about which his father used to say sometimes that English has changed his children's lives. At the day when his father's speech becomes viral over social media, Aneeka comes at Eamonn's home. Eamonn thinks that due to rain she became wet. And during drying her hair he asks Aneeka, "Does anyone give you a hard time because of the hijab? (Shamsie, 2017, p. 90)". She replies that females most of the time gets hard time for whatever they wear. She tells about different reasons of hard time that sometimes people become more hostile due to what happens as due to "Terrorist attacks involving European victims. Home Secretaries talking about people setting themselves apart in the way they dress (p. 90)". And she also tells him that she was not showering in the rain but "some guy spat at me on the Tube (p. 90)". It means that she faces this situation due to her hijab. During all this conversation Eamonn remains silent. He knows about what Aneeka is talking. Then what Aneeka speaks, it's a big reality and the reason of disintegration in the societies. So, she asks him that what he does when his father makes a speech like that. She asks, does he say,

Dad, you're making it OK to stigmatize people for the way they dress? Do you say, what kind of idiot stands in front of a group of teenagers and tells them to conform? Do you say, why didn't you mention that among the things this country will let you achieve if you're Muslim is torture, rendition, detention without trial, airport interrogations, spies in your mosques, teachers reporting your children to the authorities for wanting a world without British injustices? (p. 90, 91)

Shamsie through the above quoted lines, accentuates that the Muslim politicians like Karamat Lone does all this to prove themselves one of the Non-Muslims and tries to make their political position strong to get more higher rank. They don't care how much hard time Muslim community faces due to them. And due to the politics of Karamat Lone to maintain and increase his power, he doesn't only lose the life of his own son but his son's beloved, Aneeka and her brother, Parvaiz also.

\section{Findings and Discussions}

The researchers have taken two novels of Pakistani writers, A Case of Exploding Mangoes (2008) by Mohammad Hanif and Home Fire (2017) by Kamila Shamsie for the present study. The research questions raised at the start of the study has been logically answered in the lights of findings obtained through text analysis.

\subsection{What Is the Depiction of the Politics in Shamsie's Home Fire and Hanif's A Case of Exploding Mangoes?}

Both novels are based on politics. As it had been pointed out in analysis of $A$ Case of Exploding Mangoes that how General Zia-ul-Haq did politics to supersede Zulfiqar Ali Bhutto to get hold over the whole country and its nation. According to writer, General Akhtar, General Beg, Major Kiyani, and Ali Shigri do politics to kill General Zia-ul-Haq. CIA spooks do politics to maintain their hold over Islamic countries. Same thing is highlighted in Home Fire, as Karamat Lone does politics to get higher political position, Aneeka Pasha does politics to save her brother, Parvaiz Pasha's life, Isma Pasha does politics to save her sister's and her life from difficulties, and Farooq does politics to trap Parvaiz and use him for terrorism. There is politics at different levels in both novels such as personal, social, and civil/political, but politics at military level is found out only in the novel A Case of Exploding Mangoes. The study highlights personal politics in Home Fire through the relations between the lover and his beloved, Eamonn and Aneeka Pasha; between two sisters, Isma Pasha and Aneeka Pasha, between the father and his son, Karamat Lone and Eamonn; and between two friends, Parvaiz and Farooq, and in A Case of Exploding Mangoes, between the husband and his wife, General Zia-ul-Haq and the First Lady. Politics at social level is highlighted in A Case of Exploding Mangoes through the Pakistani media which does politics to present to the people what Army wants from them to present, through the character of the Secretary General of All Sweepers Union through whom Hanif points out in the novel the politics of army at social level. In Home Fire, social politics is accentuated through what behaviour Aneeka faces from British people due to the laws which Karamat Lone passes; which become the cause of disintegration in the society and increase more problems for Muslim community in Britain. Politics at civil/political level is found out in both novels. As in $A$ Case of Exploding Mangoes through the ruling era of General Zia-ul-Haq as a President of Pakistan and his politics to maintain and make his ruling time period longer. In Home Fire, politics is revealed through the newly elevated Home Secretary of Britain, Karamat Lone. Politics at military level is found out only in $A$ Case of Exploding Mangoes through the characters of General Zia-ul-Haq, General Akhtar, General Beg, Major Kiyani, Ali Shigri, and CIA spooks.

\subsection{What Kinds of Political Imbroglios at Different Levels Are Present in Shamsie's and Hanif's Novels?}

The study has brought to light in the analysis that politics works in both novels and due to the working of politics at different levels complex, intricate, and confused situations have been created at those levels. Because eople become confused and mistrusted due to duality and politics that they can't understand who is true and who is liar. 
As in A Case of Exploding Mangoes due to the politics of General Zia-ul-Haq at personal level, such a complex situation becomes created that his wife doesn't believe and love her anymore instead she considers herself a widow. In Home Fire, Isma, Aneeka, Karamat Lone, and Farooq do politics in the name of family, love, and friendship. Aneeka plays love drama with Eamonn so that he would help her to bring her brother, Parvaiz back from Raqqa and due to her politics, a time comes when Eamonn becomes confused and doesn't understand that he should believe on her love or not; Isma gives about her brother, Parvaiz the whole information to the British police to save her sister and herself from difficulties and hides it from her younger sister, Aneeka. Due to it an intricate situation becomes created that Aneeka doesn't believe on Isma anymore for anything and Parvaiz becomes dead; Karamat Lone does politics with his son. He says to his son that if he'll leave Aneeka then he'll help her and her brother. Eamonn does this but Karamat Lone doesn't do anything for Aneeka instead he takes revenge from her for using Eamonn for herself, so, such a complicate situation becomes created that Eamonn starts hating his father and due to these political imbroglios, Eamonn and Aneeka die. Farooq does politics with Parvaiz and shows himself very loyal and sincere friend of Parvaiz. Parvaiz is innocent and he believes on Farooq. Due to Farooq's mischievousness Parvaiz becomes mistrusted and confused, and can't understand upon whom he should believe or not, and at the end Farooq himself kills Parvaiz.

At social level, in A Case of Exploding Mangoes political imbroglios become prominent due to the politics of army and media that create disintegration in the society and as farmers and sweepers become separated because their unity is being destroyed by the army's interference in agriculture. In Home Fire, politics at social level is highlighted through the depiction of the British politicians', media's and people's hate and attitude towards migrants there due to which such an intricate situation comes into being that disintegration becomes created in the society which becomes the cause of destruction.

In A Case of Exploding Mangoes, at civil/political level, political imbroglios are created by General Zia-ul-Haq as he hanged Zulfiqar Ali Bhutto. In Home Fire, Karamat Lone does politics at civil/political level and creates complex and confused situations as he passes new laws against Muslim community and other migrants there to make his political position strong which becomes the reason of creating complications in the country and in his life also. The politics at military level is highlighted through the Pakistan army and CIA spooks at national and international level to maintain their hold and power over Pakistan as General Zia-ul-Haq, General Akhtar and CIA spooks don't want to stop the wars in Islamic countries so create confusions to continue the wars, and as Lieutenant Bannon creates political imbroglios through using Obaid ullah against his friend, Ali Shigri, and Obaid ullah doesn't know the politics behind this confusion but Ali Shigri comprehends that his friend is being used against him and that there is must someone behind it, and as General Zia-ul-Haq's killing of Colonel Quli Shigri also created imbroglios.

\subsection{What Are the Reasons of the Conversion of Politics into Capitalism in Hanif's and Shamsie's Novels?}

As in both novels, the researcher has found out politics and political imbroglios at different levels, it has been clear that different characters do politics at different levels. But General Zia-ul-Haq and General Akhtar in the novel A Case of Exploding Mangoes, and Karamat Lone in the novel Home Fire, do politics as capitalists. They suppress the others through their economic and political power. They always try to keep the others under their control. They don't want that anyone else comes in equal position and power as they have. They believe that they have all the power and can do anything right or wrong with anyone. They do wrong with others even ruin their lives and careers. They want to be the most powerful men in their countries that the whole country and its nation would be under their control. As General Akhtar does with General Zia-ul-Haq and Akhtar Masih; and General Zia-ul-Haq does with General Akhtar, Colonel Quli Shigri, Secretary General of All Pakistan Sweepers Union, and blind Zainab. As Karamat Lone does with Pasha family, the Muslim community, and other migrants in Britain. Even Karamat challenges Allah Almighty in the arrogance of his political and economic power which he forgets is bestowed him by Allah. Mohammad Hanif throughout the novel presents army as a bourgeoisie and others as proletariat, and Kamila Shamsie also presents Lone family as a bourgeoisie and Pasha family as proletariat. Throughout the novels, the upper class suppresses the other and gets personal benefits from them.

\subsection{How Political Mantles Are Represented/Misrepresented Pakistani People, Culture and Society?}

The study has highlighted the political oligarchy at different levels in both novels through applying the theory Marxism and its sub-theory Capitalism. As Marxism is an economic system that structures human societies, Marxist methodology is used originally a method of socio-political and economic inquiry known as historical materialism to critique and analyse capitalism's development and role of the class struggle in the systematic economic change. So, it's used to analyse and interpret all individual, social, political, cultural, historical events from economic point of view. Lois Tyson further says that Marxists believe that behind every activity of life, 
there is a force of economic power that drives them. According to the Marxism theory, people do politics and maintain dual personality to gain personal benefits and to gain political and economic power, and fame. In the present study, the researchers have highlighted that at what level all the characters do politics, they do it for their personal benefits and some for political and economic power also.

\subsection{What Are the Causes of Intermingling of Religious Values into Political Values?}

According to Tyson (2006), Karl Marx called religion "an opiate". For Karl Marx and other Marxists, the existence of God isn't an issue but what human beings do in the name of God and organized religion is the focus of them (ibid, p. 59). It is also highlighted in both novels that significance presence of the intermingling of religious values into political values can be seen. There is exploitation at huge level through using religion in both novels. No other thing can cause the destruction at such a large scale as religion does because people love their religion. As in Home Fire, Farooq, one Scottish, and one American do politics with Parvaiz using religion which exploits Parvaiz Pasha and takes his life; and Karamat Lone uses religion to get political and economic power. Same happens in A Case of Exploding Mangoes, as General Zia-ul-Haq shows himself religious and pious so that nobody can comprehends his duality and mischievousness. According to Hanif (2008), he wears the cloak of religion so that people like him. He introduces and passes new Islamic laws also but he himself not follows those laws. Hanif (2008) asserts that Zia takes guidance from holy Quran for politics but just use it for his own personal benefits, not for the benefit of the country and its nation.

Bringing up rear all the above analysis and discussion, it has been clear that both novels are replete with politics, political attitudes and political benefits and threats. Study has brought to light the reasons for which people do politics and create political imbroglios. To get personal benefits and political and economic power, people play politics and cheat others, and those who get economic and political power, work in their societies like capitalists and ruin the life and careers of others for their own personal benefits and also to maintain and increase their power. The study has also explored the similarities and dissimilarities in both novels through comparative analysis. It has highlighted in the analysis that there is politics and political imbroglios in both novels but both novels have politics at personal, social, and political/civil level. However, politics at military level is found out only in Mohammad Hanif's novel, A Case of Exploding Mangoes (2008). The researchers have come to conclusion that if the politicians stop corruption and become sincere and honest with us and our country, army will stop their interference in political/civil and social matters of the country. In both novels, the current study has found out the conversion of politics into capitalism and the working of capitalists for their personal benefits. Study has also explored in the wrong use of religion for politics and highlighted the destruction due to it. Findings also reveal the negative impact of politics, political imbroglios, capitalism, and intermingling of religious values into political values.

\section{References}

Adams, I., \& Dyson, W. R. (2003). Fifty Major Political Thinkers. London: Routledge.

Ashraf, A. (2014). A message of Globalization: An Analysis of Contemporary South Asian English novels. International Journal of Scientific and Research Publications, 4.

Dorling, D. (2016). A Better Politics: How Government Can Make Us Happier. London: London Publishing Partnership.

Fatunla, M. D. (2015). Whats on Africa. Book Review: Black Sunlight.

Filkins, D. (2016). Dangerous Fictions: The Writer Mohammad Hanif probes for truth in Pakistan. The New Yorker.

Hanif, M. (2008). A Case of Exploding Mangoes. US: Harvard University Press

Hassan, F. (2016). The Empire Writing Back: Contemporary Pakistani Novel in English. American International Journal of Contemporary Research, 6(2).

Inskeep, S. (2012). Mohammed Hanif on Secrets and Lies in Pakistan. National Public Radio: USA.

Paul, V. T. (2016). Wiley Online Library. Real Simple. Penguin Random House.

Rodrik, D. (n.d.). Harvard University Press. University of Pennsylvania Press.

Schaub, M. (2017). Home Fire puts a Topical Spin on Ancient Greek Tragedy. NPR 15 Aug. 2017. Web. 02 Jan 2017.

Scott, R. B. (2006). The Political Economy of Capitalism. Cambridge University Press.

Shamsie, K. (2017). Home Fire. USA: Riverhead. 
Tanveer, Y. M., \& Arif, S. (2014). Praetorianism in a Case of Exploding Mangoes: A Critical Analysis. Research on Humanities and Sciences, 4, 95.

Tyson, L. (2006). Critical theory today. London: Routledge.

\section{Copyrights}

Copyright for this article is retained by the author, with first publication rights granted to the journal.

This is an open-access article distributed under the terms and conditions of the Creative Commons Attribution license (http://creativecommons.org/licenses/by/4.0/). 